\title{
JAMES KEILL OF NORTHAMPTON, PHYSICIAN, ANATOMIST AND PHYSIOLOGIST
}

by

\author{
F. M. VALADEZ and C. D. O'MALLEY
}

JAMES KeILL (1673-1719), author of the most popular English anatomical compendium of the close of the seventeenth and early part of the eighteenth centuries, also enjoyed renown in the latter century as one of Britain's leading iatromathematical physiologists. A biographical account of Keill appeared in the Biographia Britannica, ${ }^{1}$ and Haller, ${ }^{2}$ Portal, ${ }^{8}$ Diderot, ${ }^{4}$ and Mangetus ${ }^{5}$ considered his work sufficiently significant to merit extended discussion. By the end of the eighteenth century, however, Keill's anatomy had been eclipsed by subsequent and more up-to-date compendia, and because of the new vitalistic trend in physiological thought, his efforts to reduce the processes of physiology to mathematical terms were discounted as mere idle speculation. In consequence, and unfairly in view of his earlier recognition, Keill's achievements suffered an almost total disregard.

With the exception of a brief article by J. F. Payne in the Dictionary of National Biography, this neglect of Keill has continued down to the present day. Although he was by no means on the level of the great seventeenth-century English anatomists and physiologists-Harvey, Willis, and Lower-his anatomical treatise may be said to have displayed a respectable competence at a time when anatomical instruction in the medical faculties of Oxford and Cambridge declined precipitously and in fact reached its nadir, and his physiological studies revealed a genuine interest and sincerity even if the problems he sought to solve were beyond the capabilities of anyone of his day.

In addition Keill practised medicine in Northampton and the surrounding area of the county. Through a series of letters that he wrote to the celebrated London practitioner Sir Hans Sloane (1660-1753)-unfortunately Sloane's replies are not known to be extant-one is able to obtain a picture of the provincial physician, in Keill's case possibly as capable as his London colleagues, but simply because he was a provincial physician, often questioned as to his judgment by his patients who demanded that his medical decisions be confirmed by consultation with some Fellow of the august Royal College of Physicians. Keill's letters seem to indicate that at least some of his practice, especially patients in the higher ranks of society, were in fact Sloane's patients who happened to have estates somewhere in the neighbourhood of Northampton. Treated by Sloane when in London, when in residence in Northamptonshire their medical problems were handled by Keill. He was in consequence obliged to send reports and queries regarding their treatment to Sloane who would

1 Biographia Britannica, London, 1757, vol. 4, pp. $2809-11$.

A. von Haller, Elementa physiologiae corporis humani, Lausanne 1757 vol. 1, pp. 448-52.

- A. Portal, Histoire de l'anatomie et de la chirurgie, Paris, 1770, vol. 4, pp. 217-20.

-D. Diderot, Encyclopédie, [article: 'Coeur'], Paris, 1753, vol. 3, pp. 596-600.

B J. J. Mangetus, Bibliotheca scriptorum medicorum, Geneva, 1731, vol. 3, pp. $45-48$. 


\section{F. M. Valadez and C. D. O'Malley}

himself travel to Northamptonshire in cases of emergency. In short, Keill seems, in part, to have been operating a branch office for Sloane, but whether as a mere convenience for him or whether Sloane in any way profited financially is nowhere indicated.

James Keill was born in Edinburgh, Scotland, on 27 March 1673, ${ }^{\circ}$ the younger brother of John Keill (1671-1721), who was ultimately to gain distinction as Savilian Professor of Astronomy at Oxford. James was also the brother of Magdalen Keill who through marriage became Mrs. John Murray of Northampton and was remembered in James' will together with her children. That will also refers to James' uncle 'Dr. Cockburn' who was William Cockburn, M.D. (1669-1739), ${ }^{\text {Swift's }}$ 'honest Dr. Cockburn' and the translator of Walter Harris' early study of paediatrics, De morbis acutis infantium (1689).

James and John Keill began their university studies together in Edinburgh at a time when for the most part the system of regents, who taught every subject in the curriculum, prevailed rather than the professorial system. The one firmly documented reference to James' student years at Edinburgh is to be found in a list of those enrolled with Andrew Massey, regent in philosophy for the year $1688 .^{8}$ However, a professorship in mathematics did exist, held by David Gregory from 1683 to 1692. John Keill, an ardent Newtonian, was one of Gregory's pupils, and because of James' later concern with mathematics and Newtonian thought as it might be applied to physiology, it seems not unlikely that he, too, attended Gregory's classes. Unfortunately there is no extant class list to substantiate this possibility.

Although John Keill continued his studies at Edinburgh and graduated in 1692, James chose to proceed to the continent for that medical training which Britain of the seventeenth century could not provide. In Paris Keill attended the chemistry course of Nicolas Lemery (1645-1715) and later described how 'Commonly he runs through his Course of Chymical Operations in seven or eight Weeks time, and allows three or four Days each Week for his Lectures and Operations.' The thirty-four lectures Keill heard covered such topics as 'The Distillation of Wine into Brandy' to 'The ninth and last sublimation of the Panacea'.10

It seems likely that in Paris Keill also visited the anatomical demonstrations of Jean Guichard Duverney, ${ }^{11}$ whose reputation had been established ten years earlier with his famous Traité de l'Organe de l'Ouie (Paris, 1683). His well-attended lectures were said to be especially popular with foreign students. ${ }^{12}$

By 1696 Keill had arrived at the University of Leyden where his matriculation is

- Biographia Britannica, vol. 4, p. 2809, from information supplied by Keill's nephew, John Murray, who, as will be indicated later, figured in Keill's will as one of his heirs together with a second nephew, William Murray, and two nieces, Elizabeth and Sarah. Keill's will also mentioned a 'Brother and Sister Gordon' which suggests a second married sister. Although there is no actual statement that James Keill was born in the city of Edinburgh, this seems likely since it was the native city of his slightly older brother, John.

Cf. the biography of Cockburn in the Dictionary of National Biography.

- University of Edinburgh, Matriculation lists, 1688, fol. 127. Courtesy of Beth Brown, Department of Manuscripts.

- University of Edinburgh, Graduation records, 29 August 1692.

${ }_{10} \mathrm{~N}$. Lemery, A Course of Chymistry ... the third edition, translated from the eighth edition in the French, London, 1698, preface.

${ }_{11}$ N. F. J. Eloy, Dictionnaire historique de la Médecine ancienne et moderne, Mons, 1778, vol. 2, p. 633.

12 Biographia Britannica, London, 1763, vol. 6, pt. 1, p. 3699; Portal, op. cit., vol. 3, p. 466. 
recorded on 16 October of that year, ${ }^{13}$ although the length of his stay is unknown and it appears most likely that he did not receive a degree. It has been suggested that at Leyden Keill studied anatomy with Anton Nuck and Govert Bidloo, and although Nuck's death in 1692 would make it unlikely that he had been an instructor of Keill, it was probable that he was able to hear Bidloo, who had assumed the chair of anatomy in 1694. Unfortunately Bidloo's capabilities as an anatomist were not equalled by his devotion to his professorial duties and Keill's anatomical training at his hands may not have been as thorough as one would have expected from a man of Bidloo's skill. ${ }^{14}$

Nonetheless even Keill's limited education abroad provided him with a knowledge of anatomy superior to that which could be acquired in any English university. At Cambridge there was no professor of anatomy until 1707 and prior to that time, as early as 1692, the void was filled by some private lectures given by an Italian of whom nothing is known, not even his name, and at some time after 1701 by George Rolfe, already an independent teacher of anatomy in London. In 1707 Rolfe was awarded the official title of Professor of Anatomy at Cambridge and promptly became professor in absentia. ${ }^{15}$

At Oxford unofficial instruction in anatomy had been sporadically offered around this time also by 'an Italian', by Edward Hannes (d. 1710) and by William Musgrave (1656-1721). ${ }^{16} \mathrm{~A}$ provision for a regular anatomical lectureship, the Tomlins Readership, had been established in 1624 as a concurrent appointment for each succeeding regius professor of medicine. However, despite a promising beginning, the readership had not proved a lasting stimulus to anatomical teaching and the resultant neglect of this subject is well illustrated by the career of Thomas Hoy, named regius professor in 1698. Hoy's apparent inability to fulfil the duties of the readership is suggested by an uncharitable contemporary jest 'abest demum Anatomiae Professor, because he's afraid to see a Skeleton'. ${ }^{17}$

Oxford's medical students, like their Cambridge counterparts, were thus wholly dependent on a few private anatomical teachers, whose small number Keill soon joined upon his return to England. Keill had lectured at both Oxford and Cambridge by 1700 according to a letter written in that year by John Wallis. ${ }^{18}$ The Biographia Britannica adds that Keill's lectures at both universities were received 'with great applause', although it does not mention when he started or ceased. ${ }^{19}$

Presumably, however, Keill felt himself sufficiently prepared to lecture on anatomy as early as 1698 for in that year he published the first edition of his popular Anatomy of the Humane Body abridged (London). The book is dedicated to Edward Tyson (1650-1708), lecturer in anatomy at Chirurgeons' Hall and England's leading com-

12 R. W. Innes Smith, English-speaking Students of Medicine at the University of Leyden, Edinburgh, 1932, p. 131.

14 G. A. Lindeboom, Herman Boerhaave, London, 1968, pp. 59-60.

15 A. Rook, 'Medicine at Cambridge 1660-1760', Med. Hist., 1969, 13, 118.

16 R. T. Gunther, Early Science in Oxford (Life and Letters of Edward Lhwyd), Oxford, 1945, vol. 14, pp. 135-36.

${ }_{17}$ T. Hearne, Remarks and Collections of Thomas Hearne, ed. C. E. Doble, D. W. Rannie, and H. E. Salter, Oxford, 1885-1921, vol. 2, p. 461.

${ }_{18}$ T. W. Jackson, 'Dr. Wallis' letter against Mr. Maidwell, 1700', Collectanea (1st ser.), ed. C. R. L. Fletcher, Oxford, 1885, pp. 316-17.

${ }_{10}$ Biographia Britannica, vol. 4, p. 2809. 


\section{F. M. Valadez and C. D. O'Malley}

parative anatomist whose encouragement Keill credits with having led him to publish the work and whose 'private Favours and Civilities' Keill acknowledges. The dedication was retained in later editions but Tyson appears not to have figured further in Keill's career.

As a small, concise compendium, Keill's Anatomy filled a definite gap in English anatomical works of that time but it was hardly an original effort. Keill himself made no secret of the fact that his 'small Pocket-Book', as he described it, was based upon the anatomical epitome of ' $M$. Bourdon ... who has expressed some things especially in his first Chapter, so briefly, and yet altogether so fully, as that I thought I could not do better than to Copy after them.' 20

'M. Bourdon' was Amé Bourdon (1638-1706),"1 a French physician from Cambrai, today little known, but who in his time had published a book of anatomical plates and a short, well-received compendium, Nouvelle description anatomique de toutes les parties du corps humain, et de leurs usages (Paris, 1679, 1683 or 1684, 1687). Unlike Bourdon, Keill offered no accompanying illustrations although he otherwise followed the general plan of Bourdon's epitome and, in fact, many of Keill's paragraphs are verbatim translations from throughout the whole of Bourdon's text rather than merely the latter's first chapter. Thus Keill's first book appears to have been a somewhat hasty production by a young physician who perhaps hoped it would provide, along with his anatomical lectures, a financial supplement to his incipient medical career.

However, some sections of Keill's Anatomy, such as that on the brain, diverge considerably more from Bourdon than the earlier pages. It is thus incorrect to call it simply a copy of the French work, for although it appears that Keill had a copy of Bourdon's work in front of him when he wrote his own, he had no hesitation in adding sentences or paragraphs to Bourdon's text, deleting items such as clinical references, and otherwise rearranging material as he saw fit.

It was also in 1698 that Keill brought out a translation or rather a revision and completion of the translation begun by Walter Harris of Nicolas Lemery's Course of Chymistry. Harris (1647-1732), a London physician and also a student of Lemery in Paris, had previously translated two earlier editions of the Frenchman's wellreceived text. However, regarding Harris' preparation of a third English edition, as Keill wrote, 'his affairs not permitting him to go through with it, he imposed this Task upon me, that the Bookseller might not be disappointed.'22

In the midst of his literary chores, Keill took time to evaluate his own status. Despite his continental studies, he seems to have possessed no medical degree and this might explain the absence of his name from the title-page of the first edition of his Anatomy although he had signed the dedication. Whether because Keill felt the M.D. degree necessary for his anatomical lectures at the universities or for the establishment of his medical practice in Northampton, which as will be indicated later, was soon to

20 J. Keill, The Anatomy of the Humane Body abridged, London, 1698, preface.

21 For a biography of Bourdon, see Société d'Emulation de Cambrai, Mémoires, 1894, 49, $39-44$.

22 Lemery, loc. cit. J. R. Partington also lists a second and posthumously published translation of Lemery by Keill, A Course of Chymistry . . tr. by Jas. Keill from the 11 French ed., London, 1720 (A History of Chemistry, London, 1962, vol. 3, p. 30). Keill's uncle, William Cockburn, as aforementioned, translated Harris' book on paediatrics from Latin to English. They would all, under any conditions, being in medicine, have been acquainted, but perhaps it was through Cockburn that Harris' incomplete translation of Lemery was handed on to Keill for the third edition. 


\section{James Keill of Northampton}

transpire, he next undertook to gain a Scottish degree, which could be had at that time for no more than a fee and a thesis. Let it be said on Keill's behalf that he was probably better trained than many who had graduated M.D. at Oxford or Cambridge.

There is a record among the graduates of Aberdeen in May 1699 that James Keill received one of that university's somewhat dubious degrees. It is only thus that one may interpret the phrase, 'Dr. Keil frater. Hic Scotus apud Anglos floruit, scriptis suis clarus' which could at that time have been a reference only to Keill's anatomical compendium published in the previous year. Among the library accounts is a further statement that ' $D r$. Kyle paid $\mathrm{f} 60$ Scots'. It seems to have been the custom for graduates to make a payment to the library funds, and in Keill's case, since the pound Scots was worth about $1 s .4 d$., he contributed $f 4$ in English currency. ${ }^{23}$

Keill was later to receive an honorary M.D. degree from Cambridge, 16 April 1705, in consequence of a visit of Queen Anne to that university. ${ }^{24}$ However, it was clearly his earlier degree which sufficed to establish his provincial practice and which adorned his name on the title-page of the second edition of his Anatomy published in 1703. That Keill now felt the work was much more his own effort is indicated by his omission in this and all subsequent editions of the preface in which he had so generously recognized Bourdon's contribution. Indeed this new edition, described by Keill as 'revis'd' did represent a considerable advance over Keill's earlier version and reflected additional reading, reflection and personal research on the cadaver. In addition to purely mechanical changes resulting in a better style and more concise expression of ideas, Keill emerged as a much more sophisticated writer who readily expressed his own opinion in controversial matters and whose conceptual prejudices now denoted an iatromechanist.

For the first time Keill acknowledged familiarity with the works of Sanctorius, ${ }^{25}$ of Borelli, ${ }^{26}$ and of Archibald Pitcairne (1652-1713), 'that great Improver of the true Theory of Physick'27 whose studies on the force of stomach movements and the force of air upon blood in the lungs impressed Keill very much. For his new edition Keill himself had attempted to compute the pressure of the air upon the lung's blood-vessels ${ }^{28}$ and had begun his study of secretion with an attempt to measure bile production in a dog. ${ }^{29}$ More importantly he had worked out the rudiments of his theory of glandular secretion to be presented more fully in his physiological treatise five years later. In his earlier work one may already note his concept of a secretion as a 'cohaesion' formed from particles in the blood ${ }^{30}$-a concept which foreshadowed his later fascination with a hypothetical attractive force between particles of matter and which for Keill became a favourite explanatory tool in physiology.

In addition to pursuing his own scientific interests, Keill also attempted to promote the career of his brother at this time in a letter dated 6 November 1703, which also provides the first indication of his residence in Northampton. ${ }^{31}$ The letter was directed

* P. J. Anderson Officers and Graduates of University and King's College Aberdeen 1495-1860, Aberdeen, 1893, p. 123.

university of Cambridge, Subscriptiones, 1691-1724, vol. 3, pp. 233-34.

26 J. Keill, The Anatomy of the Humane Body abridged, the second edition, revis'd, London, 1703, p. 15.

Ibid., p. $23 .{ }^{27}$ Ibid., p. 37.

28 Ibid., p. 124.20 Ibid., p. 64.

20 Ibid., p. 56.

31 Eloy, loc. cit., states that Keill settled in Northampton in 1700 . No evidence is given, but it may be recalled that he received his Aberdeen degree in 1699. 


\section{F. M. Valadez and C. D. O'Malley}

to William Fermor, Lord Leominster (1648-1711), who before gaining his peerage had been the parliamentary representative of Northampton and continued to reside at Easton Neston, Northamptonshire. As an acquaintance by proximity as well as through 'the honour your Lordship has always done me and the condescension and goodness in expressing your undeserved kindness,' Lord Leominster's influence was sought on behalf of the appointment of John Keill, then at Oxford, to the Savilian Professorship of Geometry in succession to the mathematician John Wallis, deceased in that year. However, James was realistic enough to add that if Mr. Halley . . . will accept of it we will have no more to say. ${ }^{32}$ In fact Halley, the celebrated astronomer, did accept the professorship, no doubt to the disappointment of the Keill brothers until in 1712 John received the Savilian Professorship of Astronomy.

The remainder of Keill's correspondence known to be extant is of a medical nature. Except for one letter to James Petiver, a London apothecary, all of it is addressed to Sir Hans Sloane who appears to have been his patron and court of appeal for difficult medical problems. Indeed one may conclude with fair certainty that Keill's practice in Northampton, at least as far as his care of the peerage was concerned, represented local treatment of patients temporarily away from London and Sloane's direct care of their health problems. Keill's clinical ability, as revealed in this correspondence, was not characterized by new insights into diseases or by innovative methods of treatment; he may indeed be termed conservative in his practice which seemed to remain generally unaffected by his extensive physiological researches. Nevertheless he emerges as a conscientious practitioner, capable of sending objective clinical descriptions to Sloane for the latter's advice, although if the case were sufficiently important Sloane would make a personal visit to the patient.

One of Keill's first patients of whom we have a record was Charles Tryon of Bulwick, a young man of twenty-seven. The first letter to Sloane, 14 October 1705, indicates either that Keill had recommended a consultation or that the young man's family thought one advisable. 'Madam Saville will wait on you upon account of her son Mr. Tryon who has been my patient now these two months.' Tryon was a member of a local social group, the Honorable Order of the Little Bedlam, organized at Burghley, in which the Bedlamites at their 'innocent frolic', as it was described, were called by the names of animals. Tryon was the Otter. ${ }^{33}$ Bedlamite frolics, as well as intemperance on other occasions had destroyed his appetite and he was 'reduced from a strong lusty man to almost skin and bones.' Restored, according to Keill, through the usual drugs of the day, both stimulant and purgative, 'some pills of gum ammon [iac] rheum [rhubarb] and steel [wine in which iron filings had been steeped], with a bitter infusion ... . he began again to make bold with his constitution' and developed 'a great cough which by drinking and burnt brandy [merely brandy] and treacle (prescribed by some old women) is now turned into a spitting of blood.' The diagnostic signs, still including uroscopy, revealed that 'his water is high coloured and his pulse very quick.' For these new disorders Keill gave 'asses milk, a tincture of roses and a pectoral linctus' and bled him twice to a total of fourteen ounces, the blood being 'of a buff colour'. 34

22 British Museum, Add. Mss. 29589, fol. 305.

23 Northamptonshire Notes and Queries, Northampton, 1886, vol. 1, pp. 9-10.

2 British Museum, Sloane Mss. 4059, fol. 238. 


\section{James Keill of Northampton}

A second letter, written nine days later from Bulwick Park notes that the bleeding had stopped. However Keill had found he could not employ his medicament of choice since 'The very sight or name of the [Peruvian] bark does put him in an agony's5 so he substituted other standard astringent and sedative drugs-infusion of terra Japonica with laudanum at night and a little diacodium (syrup of poppy heads) and a pectoral drink in the day. Unfortunately Tryon's fever still had almost no remission and was accompanied by a pulse rate of ninety on which basis Keill wrote, 'You will be easily persuaded that we have too much reason to fear the worst. ${ }^{36}$ His prognosis was borne out by the young man's death on 7 November. ${ }^{37}$

As Keill's later publications would indicate clearly his interest in the quantification of physiology, so Tryon's case demonstrates that at least in one instance he had applied that quantitative interest to clinical medicine by counting the pulse beats. It is true that various methods of timing the pulse had been attempted earlier by a few, but not many, at least in England, had attempted anything of this sort. The first watch with a second hand was the pulse watch of Sir John Floyer described in his Physician's Pulse Watch (1707). ${ }^{38}$ Keill must have used the somewhat less accurate device of a minute hand. Nevertheless he was certainly one of the few in England at that time to observe the quantity rather than the quality of the pulse, which contrasts markedly with his efforts to diagnose from the appearance of the urine and on the basis of the colour of the blood.

It may also have been about this time that Keill was caring for a Mr. Elberand, who, among other things, suffered from a swollen leg and an inclination to 'scurvy' against which latter complaint a 'diet drink' had been prescribed. Elberand had also been the victim of some sort of fever but had recovered despite Keill's fears, almost medieval in character and displaying one of the unscientific traditions of medicine of that period, 'of the full moon having observed it fatal in such cases and his last fever fitt was at that time'. ${ }^{39}$

Another patient was a Mrs. Dow, a 'gentlewoman of almost 70 years of age,' whose constipation was susceptible only to a clyster, and who 'every night takes a quieting draught of 35 drops of laudanum'. ${ }^{40}$ In response Sloane had recommended some purges which 'never moved her in the least tho' she took them three times.' She then sought advice from Dr. Pitt, presumably Robert Pitt (1653-1713) F.R.C.P., 'who sent her a purging electuary but had no effect at all'.41

In 1706 Keill was concerned with an ancient inhabitant of Northampton, John Bayles, a button-maker, who died on 4 April 1706. There is no indication that he had been Keill's patient, although the latter had at some time earlier become interested in the phenomenon of longevity and examined Bayles at least to the degree of having felt his 'irregular and intermitting Pulse ... some years before he dyed'. Partly because

\footnotetext{
as The Peruvian bark was probably recommended to Keill by Sloane who had invested heavily in its purchase. As it would appear from Tryon's case, Sloane was not adverse to promoting its virtues for a variety of ailments other than malaria which was apparently not Tryon's illness. See B. Chance, 'Sketches on the life and interests of Sir Hans Sloane: naturalist, physician, collector and benefactor', Ann. med. Hist., 1938, 10 (new ser.), 396.

${ }^{86}$ British Museum, Sloane Mss. 4040, fol. 83

$\because 7$ J. Bridges, The History and Antiquities of Northamptonshire, London, 1791, vol. 2, p. 319.

'Cf. G. L. Townsend, 'Floyer on pulse and respiration', J. Hist. Med., 1967, 22, 286-316.

๑o British Museum, Sloane Mss. 4039, fol. 275.

4 British Museum, Sloane Mss. 4078, fol. 178.

1 British Museum, Sloane Mss. 4039, fol. 287.
} 


\section{F. M. Valadez and C. D. O'Malley}

of an interest in pathological as well as normal anatomy, and partly because of the parallel to the account 'of old Parre by the famous Harvey,' Keill performed a postmortem examination of the body, reputedly between 120 and 130 years old at the time of death. That death, hedecided, was the result of 'the weakness of his Stomach, and the hardness of the Aorta,' and seemed to demonstrate that longevity depended upon a strong heart for circulation of the blood; the quality of the lungs 'by which the Air had its full effort upon every Particle of the Blood, in rendring it florid and attenuating it, that it might easily move through the contracted Channels of an old Body ... a a softness in all the Fibres, that they may easily yield to the pressure of the Blood, and by their Elasticity restore themselves to their former state, giving thereby a new impetus to the Blood'.

Keill's description of his findings and seeming recognition of the part played by arteriosclerosis, was published under the title of An Account of the Death and Dissection of John Bayles, of Northampton, reputed to have been 130 years old. ${ }^{42}$ Prior to publication he had visited London in an effort to show his report to his mentor Sloane. Unsuccessful, he left the report with his uncle Dr. Cockburn for transmission: 'I am sorry I were so unfortunate as not to be able to see you while I was at London. I left the paper about the old man with Dr. Cockburn to give you. I know not if you have received it yet. If there is anything in it which you think not particular enough let me know and I will endeavour to satisfy you in it.' There is no evidence to indicate that if Sloane read the report before publication he was responsible for any revisions. The letter concludes with a request that Sloane lend Keill his copy of Caspar Bauhin's 'De partibus corpore externis, I know not if I name the title right.' He was referring with somewhat defective Latin to De corporis humani partibus externis (Basle, 1588), but whether he wished to read it because of antiquarian interest or whether as a practising anatomist he considered such a work, well over a hundred years old, to have current value is not stated."s

Thus far there had been no important medical cases with the exception of that of Charles Tryon, and from the nature of Keill's letters to Sloane, it appears that the case had come directly to Keill rather than by referral. The first of Keill's more exalted patients to be mentioned in the correspondence was Christopher Hatton, Viscount Hatton of Gretton (1632-1706), residing at Kirby Hall about twenty-five miles from Northampton. ${ }^{4}$ Perhaps it was only at this time that Sloane decided that his more important patients might safely be left in Keill's charge. The case was a difficult one in which the viscount's complaint was complicated by a retention of urine and the fact that catheterization seemed of no avail, perhaps, as it appears, through the surgeon's unskilful use of the instrument. 'About two in the morning the operation of the catheter was repeated again but the surgeon could not get the instrument in so that no water was drawn. . . . Just now [ 8 p.m.] the catheter has been tried again with the same success as in the morning. My Lord is in great danger purely for want of a skilful surgeon. [Therefore] my Lady desires you to send down Cypriano with all imaginable speed.' 15 Cypriano, who can be identified as the cele-

is Phil. Trans. R. Soc. Lond., 1706, 25, 2247-52.

British Museum, Sloane Mss. 4040, fol. 172.

M C. the biography in the Dictionary of National Biography.

4 British Museum, Sloane Mss. 4078, fol. 171. 


\section{James Keill of Northampton}

brated Dutch surgeon Abraham Cyprianus (1656/60-1718) ${ }^{46}$ arrived but, for whatever reason, made no use of the catheter much to Keill's dismay. 'Why did Cypriano come down with intent to use it? It was certain that it was the only thing could save his Lordship's life and I am confident that those who blame me for using it would have blamed me more and with more reason if it had not been used.'47 Sloane felt it necessary to make a visit to the patient and appears to have sent remedies by means of James Petiver, the London apothecary, ${ }^{48}$ and the celebrated Dr. John Radcliffe was consulted, ${ }^{49}$ but all to no avail. Moreover, the patient became difficult and would take neither the ass's milk nor the Bath Water that Sloane seems to have suggested. ${ }^{50}$ 'After you were gone the indisposition and pain in my Lord's throat increased' and 'the defluxion of phlegm almost choaked him for above two days. His throat was all covered with a white furr but his tongue was as black as a coal tho' moist.' He had difficulty in swallowing, became weak, dispirited, restless, ${ }^{51}$ and 'in measure as his bladder filled the distention put him to such torture as would have drawn compassion from the hardest heart.'52 According to Keill, death came after 'five days suppression'. ${ }^{53}$

Although it might be desirable to have important personages for one's patients, there was always the risk, as Keill was to learn, that such importance carried as well greater danger of charges of malpractice. He had 'heard from several hands that the Physitians in London blame me mightily for the management of my Lord Hatton.' Some of the critics thought Keill to have been wrong in having the viscount catheterized even though 'his Lordship had been $\mathbf{4 0}$ hours without making water'. Others believed that Mr. Rushworth, the surgeon employed, was inept, although the post-mortem examination showed that the catheter 'had made only a small scratch on the side of the os pubis and that the passage was clear without any inflammation or swelling near it'. Nonetheless such charges could be very damaging, and although 'I have too good an opinion of you to think you are concerned in this accusation ... I make bold to give you this trouble that you may have an opportunity of doing me common justice'. ${ }^{54}$ It is noteworthy that not only did the surgeon Rushworth survive the criticism, but he retained Keill's confidence and was in attendance on the latter during his final illness in 1719.

Whenever possible, in that tradition which he may have acquired in Leyden, Keill appears to have made a post-mortem examination of such of his patients as died, at least of the most important ones. He prevailed upon Hatton's family and dutifully reported his findings to Sloane, that 'Lord Hatton had neither stone nor gravel in his bladder but only an inflammation upon the neck, which you may remember, was my opinion'. 55

In 1708 Keill published the third edition of his anatomical epitome. The mere

\footnotetext{
16 Originally from Amsterdam with a medical degree from Utrecht (1680), Cyprianus practised surgery and lithotomy in his native city with great success. Called to England in 1696 by Sir Thomas Millington, the royal physician, to remove his stone, Cyprianus remained in England where, despite his practice of surgery and at the same time because of his surgical renown, he was admitted a Licentiate of the Royal College of Physicians in 1699, and in 1700 a Fellow of the Royal Society.

47 British Museum, Sloane Mss. 4040, fol. 257.

48 British Museum, Sloane Mss. 4078, fol. 178.

${ }^{\circ}$ Ibid., fol. $177 . \quad{ }^{60}$ Ibid., fol. 172.

s1 Ibid., fol. 174. sa Ibid., fol. 177.

ss British Museum, Sloane Mss. 4040, fol. 257.

s4 Ibid.

ss British Museum, Sloane Mss. 4078, fol. 180.
} 


\section{F. M. Valadez and C. D. O'Malley}

necessity of a third edition testifies that Keill's anatomy was now in great demand, a fact supported by an advertisement in the Daily Courant of March 1708, which announced that a Mr. Smith would begin a course of anatomy at Surgeons' Hall. The further note that 'Dr. James Keill's Anatomy is lately reprinted, revised with additions,' suggests that this work was recommended as the class text. ${ }^{56}$

If one turns to the contents of this edition, it becomes clear that Keill's efforts between 1703 and 1708 had been primarily directed at the physiological studies mentioned below rather than at rewriting his anatomical treatise. Compared to the major job of revision which Keill had undertaken between the first and second editions, the changes in the third edition are relatively minor-Keill simply corrected the typographical errors of the second edition, occasionally reworded a paragraph, or made a slight addition. His most extensive revision concerned the heart's musculature in which he replaced his earlier account, a simple summary from Richard Lower's De corde with a more precise description. This time Keill appears to have supported his views with his own dissection of the heart. ${ }^{67}$

Keill may have found his studies somewhat hampered by his own medical problems at this time for he suddenly had to ask Sloane for advice regarding an ailment of his own. In a letter dated 16 May 1708, he wrote to Sloane that he had had three attacks of the stone. 'The first stone was ten days in the ureter before it passed into the bladder but it made an easier passage for the others.' However, 'none of these have passed out of the bladder. . . . Is there no means to assist Nature to throw them out? I retain my water sometimes as long as I can that it may run with the greater force. I have tried several postures but all to no purpose. How long have you known stones to lie in the bladder that have come from the kidney before they have been voided?' Sloane's reply, which is not extant, could not have been very reassuring.

The letter concludes with a reference to a new book. 'I have a little book a printing and have ordered you a copy. It is about secretion and the quantity of blood in the body. It opens a new scene in the natural philosophy of Physick.'58 Keill's remark, not without justification, referred to An Account of Animal Secretion, the quantity of blood in the humane body, and muscular motion (London, 1708), a work which placed Keill firmly among the iatromechanists, although at the beginning of a somewhat divergent course-the peculiarly English, Newtonian school of iatromechanists. ${ }^{59}$ Keill did not offer a complete system of physiology in his book but rather tried to illustrate how selected physiological questions might best be investigated by using measurement and mathematics in general and more particularly by positing an attractive force between particles of matter, an idea admittedly derived from the Newtonian-inspired theories of attraction presented by John Keill in the Philosophical Transactions. ${ }^{60}$

b6 G. Peachey, A Memoir of William and John Hunter, Plymouth, 1924, p. 15.

37 J. Keill, The Anatomy of the Humane Body abridged, the third edition, revis'd, London, 1708, pp. 111-13.

is British Museum, Sloane Mss. 4041, fol. 140.

69 For a more extensive examination of Keill's physiology, especially in relation to post-Harveian English physiology in general, the reader is referred to the excellent dissertation of Professor $\mathbf{T}$. $\mathbf{M}$. Brown, The Mechanical Philosophy and the 'Animal Oeconomy'-a study in the development of English physiology in the seventeenth and early eighteenth century, Princeton, 1968. He lists the other Newtonian physiologists as James Jurin, Henry Pemberton, and Stephen Hales.

o John Keill, 'In qua leges attractiones aliaque physices principia traduntur', Phil. Trans. R. Soc. Lond., 1708, 26, 97-110. 


\section{James Keill of Northampton}

For example James suggested that glandular secretions were actually cohesions of several sorts of particles brought together in the blood by the particles' forces of attraction and as permitted by the varying velocities of blood flow. A gland was merely a collection of blood-vessels which mechanically separated out the cohesions from the rest of the blood according to size. ${ }^{61}$ Regarding muscular motion Keill proposed in a somewhat less original vein that muscle fibres consisted of chains of vesicles. Within the vesicles were globules of blood which attracted one another thus condensing the smaller globules of air imprisoned within them. Contraction of the muscle was initiated by the arrival of animal spirits which attracted the globules of blood more strongly than they attracted each other. The blood globules were thus pulled apart, the air globules were free to expand and cause in turn expansion of the vesicles and contraction of the muscle. ${ }^{62}$

Keill's solutions for both these long-standing physiological problems cannot be termed lasting contributions, nor can Keill be described as an experimentalist of the calibre and ingenuity of Stephen Hales. Keill often preferred simply to take a few anatomical measurements and then retreat into mathematical abstractions thus producing some results wildly divergent from modern standards, e.g., his proposal that in the smallest arteries it would be possible for blood to flow at the rate of one quarter of an inch in 278 days. ${ }^{63}$ However, even in this case Keill may be credited with proposing a new problem to be solved since according to his own statement he was the first to attempt to determine the absolute velocity with which blood ran out of the aorta and travelled through the various arterial branches. In the course of these studies Keill recognized that the velocity of the blood had to decrease as the number of arterial branches (and hence the total cross-sectional area of the vessels) increased. Similarly Keill would appear to have been one of the first to try to work out the ratio of the fluid to the solid parts of the body partly through experiments involving tissue dessication. ${ }^{64}$ Finally Keill's efforts to assign a numerical value to the force of the air in the lungs during expiration could be considered an early attempt to determine intrapulmonary pressure, although as in his later study to measure the force of the heart, Keill was forced to express his answer in pounds in the absence of any other concept of physiological measurement. ${ }^{65}$

In response to the more empirically minded of his contemporaries who still adhered to the precepts of Sydenham, Keill presented in his preface a lengthy case for the utility of the study of the animal economy. Throughout the book Keill made an effort to relate his conclusions to medical practice although he appears mostly to have used his physiology to support the generally accepted medical measures of his day rather than to develop any original concepts in therapeutics. ${ }^{68}$ For instance he was able to

11 James Keill, An Account of Animal Secretion, the quantity of blood in the humane body, and muscular motion, London, 1708, pp. 1 ff.

(2) Ibid., pp. $155 \mathrm{ff}$.

68 Ibid., p. 152.

as Ibid., pp. $107 \mathrm{ff}$.

os Ibid., pp. 25ff.

68 Cf. the statement of Arthur Rook, 'The therapeutic repertoire of the country physician was essentially the same in 1660, in 1760 and even fifty years later. Most of the same empirical procedures were employed by John Symcotts in 1660 (Poynter and Bishop, 1951) and by Samuel Allvey (Rook, 1960) practising in almost the same area a century later, although the alleged rational basis for their presciptions had changed radically.' 'Robert Glynn (1719-1800) physician at Cambridge', Med. Hist., $1969,13,258$. 


\section{F. M. Valadez and C. D. O'Malley}

adjust his theories of particulate attraction to justify the use, common in medicine of his age, of steel filings as a deobstruent. ${ }^{67}$ At best Keill used his studies to suggest minor variations in traditional treatment, as for example, when he maintained that 'excessive' bloodletting as practised by some physicians would disturb the velocity of the blood, upset the mechanism of the forces of attraction and hence disturb glandular secretion. ${ }^{68}$

That Keill's treatment of his patients was not radically different from the practice of his contemporaries receives additional illustration from a further consideration of his patients. In July 1709 Keill was involved in the case of a Mr. Low, of whom he wrote pessimistically to Sloane 'Our patient Mr. Low is still alive and no man that was broke on the wheel endured the 100th part of the pain he has done. About a fortnight ago he had a blood corrupted stool which gave him great ease; his pains have since moderated but they now return violently again and I think he can hold out but a few days.' ${ }^{\circ 0}$

It was also during 1709 that Keill was concerned with the case of Lord Leominster as well as that of his son Thomas Fermor, the later Earl of Pomfret (Pontefract, Yorkshire, 1721). For the moment, however, Fermor was in London where he was under the care of Sloane to whom Keill wrote that 'I heartily wish you good success of him,' perhaps a suggestion that Fermor was a difficult patient. ${ }^{70}$ Ultimately Fermor returned to Northamptonshire and Keill took over his care and was able to write to Sloane on 28 November 1710, 'Your patient Mr. Fermor is very well and grows every day stronger. I wish I could say the same thing of his father'. ${ }^{11}$

The case of Lord Leominster was to occupy much of Keill's attention during the second half of 1709 and the two succeeding years. Leominster, to whom Keill's first extant letter of 1703 had been addressed on behalf of the latter's brother, John, appears to have been suffering from cardiac weakness and a troublesome congestion in the lungs. A considerable number of standard remedies were tried including bleeding to ease the difficulty in breathing and the discomfort of swollen legs, but with little effect until a letter of 30 August notes that all hope for the patient's recovery was lost and 'immediate death was expected for near three days together'. ${ }^{22}$ This time, however, the patient pulled through and two weeks later, 13 September 1711, Keill attempted to rally Leominster's remaining strength with Goddard's drops and Sir Walter Raleigh's cordial, both of them once more indicative of the state of the pharmacopoeia. Goddard's drops contained spirit of ammonia with various irrelevant additions such as bits of human skull and viper's flesh; Sir Walter Raleigh's cordial was equally exotic and nasty. ${ }^{73}$

At this stage Keill seems not to have had the full confidence of Leominster's wife who asked for Sloane's opinion in his own handwriting. ${ }^{74}$ She must have found his reply satisfactory because Keill was able to write later, 'Her Ladyship was mightily

\footnotetext{
67 Keill., op cit., p. 32.

${ }^{6}$ Ibid., pp. 102-3.

6 British Museum, Sloane Mss. 4042, fol. 1.

70 British Museum, Sloane Mss. 4059, fol. 236.

71 British Museum, Sloane Mss. 4042, fol. 208.

72 British Museum, Sloane Mss. 4059, fol. 180.

73 British Museum, Sloane Mss. 4078, fol. 182.

re Ibid.
} 


\section{James Keill of Northampton}

pleased to observe the good agreement there was between us and to see my practice approved of under your hand for I had given the bark before I received yours. ${ }^{75}$ At another point Lady Leominster had demanded that even Sloane consult two other physicians but not 'Dr. Garth or Dr. Gibbon' of whom she had no great opinion. ${ }^{76}$ Whatever her final choice, it was all to no avail and Leominster, dosed, blistered, purged and bled, and given various spa waters and ass's milk to drink, survived until 7 December 1711 although neither his life nor his death could be attributed to Keill's own medical decisions or such therapy as was suggested to him by Sloane. ${ }^{77}$

As in the years just preceding this case, patient care had been interspersed with the duties of authorship since in 1710 appeared the fourth edition of Keill's Anatomy. As aforementioned, the third edition of 1708 showed little modification from the second edition; Keill's energy had been devoted to his physiological treatise of the same year. However the fourth edition of Keill's Anatomy again represents a noteworthy revision, indeed the final revision, despite the many subsequent editions of the book including two more in Keill's lifetime (1714 and 1718). ${ }^{78}$ Their texts, however are practically verbatim with the fourth edition which offered, as its most significant addition, brief summaries of Keill's physiological findings in his three major areas of interest-glandular secretion, muscle action and the velocity and quantity of blood in the body. Keill's anatomical epitome in this form could thus provide for a more widespread diffusion of his essential ideas of iatromechanical physiology, especially to those who had originally sought only a brief summary of anatomy and who would have had no time for extensive reading in physiology.

In the following year Keill was charged with the case of Thomas Osborne, Duke of Leeds (1631-1712), during his final several days. ${ }^{79}$ The duke was on his way to his home at Hornby Castle, Yorkshire, but had stopped off at Easton Heston, the seat of his grandson and Keill's patient Thomas Fermor, son of the late Lord Leominster. The duke had been under the care of Sloane who appears to have gone to Northamptonshire for that purpose and had then left him in Keill's charge. 'The Duke of Leeds continued all Thursday in the same state you left him in . . . feverish and extremely light-headed. He complained frequently of the pain in his side and whatever he swallowed came up again. On Friday morning his pulse intermitted, he had a twitching of the tendons and was all in cold clammy sweat; about noon all these symptoms disappeared but he continued still light-headed .... . Still nothing went into his stomach; his vomiting continued and at night he brought up something very like corruption which smelled strong.' On Saturday morning 26 July, 'His pulse was very indistinct; he breathed with a good deal of difficulty and continued still raving and about noon he died.'80

\footnotetext{
${ }^{75}$ British Museum, Sloane Mss. 4059, fol. 206. Cf. note 35 regarding the use of Peruvian bark.

76 British Museum, Sloane Mss. 4059, fol. 228. Samuel Garth (1661-1719), physician and poet whose works included 'The dispensary', cf. biography in the Dictionary of National Biography. William Gibbons (d. 1728), cf. biography in W. Munk, The Roll of the Royal College of Physicians of London, 2nd ed., London, 1878, vol. 1, pp. 490-93.

77 British Museum, Sloane Mss. 4042, fols. 1, 8, 14, 20, 110 and infra.

78 For a complete biography of Keill's books, see K. F. Russell, British Anatomy 1525-1800: a Bibliography, Melbourne, 1963, pp. 146-50. He lists eighteen English editions of the Anatomy and further notes that the work was translated into French and probably Dutch and Latin as well.

70 Cf. the biography in the Dictionary of National Biography.

${ }^{80}$ British Museum, Sloane Mss. 4043, fol. 60.
} 


\section{F. M. Valadez and C. D. O'Malley}

On the following day a post-mortem examination was made and Keill sent a brief report of it to Sloane as well as the query whether or not a full account, a partial one or none at all ought to be published, 'considering the noise his case has made in the world'. ${ }^{81}$ The report, dated 29 July 1712 and apparently unpublished, states that

His Grace the Duke of Leeds was yesterday opened. The colon above the right kidney was mortified and the gangrene had likewise seized part of the kidney. The left kidney was wasted without any ulcer, a large stone filled the upper part of the ureter. The gula was contracted within an inch of the diaphragm and very much dilated above. In the right side of the thorax was about a pint of serum. ${ }^{82}$

It was during this period that Keill found it necessary once again to seek advice regarding his own health, or rather illness, from Sloane. 'Ever since my fit of the stone about three years since I had almost a continuous aching and uneasiness in my left kidney but now especially when I ride and I have frequently a sort of numbness all down that thigh and leg.' Furthermore he had fits of colic; his urine was thick, of a chocolate colour and finally bloody; sometimes he voided a little gravel. 'I think there is no doubt but that I have a large stone in my kidney I doubt too big to pass and I do not know of anything that can dissolve it.' ${ }^{83}$

However, if Keill found the state of his own health depressing, he must at least for a time have been returned to good spirits as a result of his election to the Royal Society in 1712 through the sponsorship of Sloane, the Society's secretary, to whom Keill wrote his thanks. 'I humbly thank you for the honour you have procured me of which I am altogether undeserving and therefore as the Society could not deign me such an honour as a reward but as an encouragement for I shall more ardently pursue the studies in which I have always delighted and endeavour that you may have no cause to repent your nomination nor they of their election.' ${ }^{84}$

In 1712 Keill was at Checkley, the home of Lady Chester, who seems to have suffered some sort of cerebral damage since she 'lost her speech'. He took four ounces of blood from her by means of cupping-glasses and applied 'blistering plaisters', but we may assume without result. ${ }^{85}$

Thereafter there is a hiatus in Keill's correspondence with Sloane until on 29 April 1715 he wrote in regard to some unnamed person who appears to have been Robert Shirley, Earl Ferrers (1677-1717), who was still taking Sloane's prescriptions although his dropsy was increasing and 'the disorders of his head increase to a degree of fury that there is no managing him'. The application of leeches to his temples had been effective but the supply had been exhausted. Lady Ferrers had thought of taking him to London and had looked into the matter of a 'horse litter'. It was probably with heartfelt thanks that Keill closed his letter saying 'I shall be very glad to deliver him safe into your hands.' 86

Two years later Earl Ferrers was ill again or possibly it was a continuation of his earlier illness. On 26 September 1717 Keill wrote to Sloane that Ferrers had become jaundiced about three weeks earlier. Keill bled him and gave him a vomit as well as

81 British Museum, Sloane Mss. 4059, fol. 233.

82 British Museum, Sloane Mss. 4043, fol. 66.

83 British Museum, Sloane Mss. 4059, fol. 212.

84 Ibid., fol. 216.

85 Ibid., fol. 215.

${ }^{86}$ British Museum, Sloane Mss. 4044, fol. 39. 


\section{James Keill of Northampton}

a variety of drugs including 'Troche of viper, cinnebar and antimony' and a 'bitter aperient Wine' with some drops of 'spirit of human urine', Keill concluded. 'I have observed no alteration in his case only he is not as loose as at first and the symptoms which you will easily see are but few.' It appears therefore that Sloane was going to pay a visit. However, despite their combined efforts, Ferrers died on 25 December $1717 .{ }^{87}$

On a more pleasant note it was in the same year that Keill published the second edition of his physiological treatise under the title Essays on Several Parts of the Animal Oeconomy (London, 1717). Aside from one large additional essay on the force of the heart, Keill considered the same problems as before. However, he rearranged the order of discussion and attempted to refine some of his calculations and numerical results although his methods and answers would still not be acceptable today.

In calculating the force of the heart, Keill hoped to correct Borelli's exaggerated conclusion that the heart possessed a force of 180,000 pounds. However, Keill's own solution of a cardiac force equivalent to a weight of 5 to 16 ounces was questioned very quickly after its publication ${ }^{88}$ In particular it provoked a scholarly response in the Philosophical Transactions from James Jurin (1684-1750) a physician and fellowNewtonian who believed Keill had not sufficiently understood the Newtonian principles he had used to obtain his result. Jurin applied more complicated theorems of his own invention and Keill's experimental data to derive his own answer of 15 pounds, 4 ounces. ${ }^{89}$ Keill replied to Jurin's objections; ${ }^{; 0}$ Jurin submitted a further essay ${ }^{91}$ and only Keill's untimely death prevented what would undoubtedly have been his second reply. The moderate and judicious tone of the disputants contrasts markedly with the bitterness of other contemporary scientific quarrels.

Tentamina medico-physica, which appeared in 1718 , is basically a translation of the Essays of the preceding year although there are certain differences between the works indicating Keill's conscientiousness and perhaps a responsiveness to minor criticism. The preface is enlarged and partially rewritten in the Latin edition to allow Keill to present a stronger plea for the usefulness of the study of the 'animal oeconomy'. In the text Keill has added a few new sentences and paragraphs and deleted others. For instance, in his chapter on glandular secretion, which was the one most changed between the two editions, Keill felt it necessary to elaborate on his concept of attraction between the particles of blood in order to stress that this force was different from the force of gravity. ${ }^{92}$ However his theories regarding function and his calculations remain the same in this chapter and the others.

Medicina statica Britannica was appended to Keill's Tentamina although it was essentially an independent work. It represented Keill's attempt to study human intake and excretion after the manner of Sanctorius whose results, Keill believed, might not be as applicable to the inhabitants of a northern country like England as they were to the Italians. The work's dedication to an old professional acquaintance, John Freind

${ }^{87}$ British Museum, Sloane Mss. 4045, fol. 49.

83 J. Keill, Essays on Several Parts of the Animal Oeconomy, the second edition corrected and enlarged, London, 1717, pp. 87-90.

of J. Jurin, 'De potentia cordis', Phil. Trans. R. Soc. Lond., 1718, 29, 863-72 and 1719, 30, 929-38.

$\infty$ J. Keill, 'De viribus cordis epistola', Phil. Trans. R. Soc. Lond., 1719, 30, 995-1000.

11 J. Jurin, 'Epistola ... qua doctrinam suam De potentia cordis, contra nuperas objectiones . . . defendit', Phil. Trans. R. Soc. Lond., 1719, 30, 1039-50.

'2 J. Keill, Tentamina medico-physica, ad quasdam quaestiones, quae oeconomiam animalem spectant, accomodata. Quibus accesit Medicina statica britannica, London, 1718, pp. 63-65. 


\section{F. M. Valadez and C. D. O'Malley}

(1675-1728), revealed that Keill made his observations regularly for one year and at leisure times for over ten years, mostly 'between the age of thirty and forty'.

Keill organized his data into tables which listed daily food intake and the quantities excreted of urine, faeces and perspiration, in addition to weight, pulse rate, wind direction, air temperature and air pressure. He noted that his thermometer was divided into 105 equidistant degrees at which 45 degrees represented the 'temperate state' of the air. ${ }^{93}$ Otherwise there was no account of Keill's techniques or tools although John Quincy (d.1722), a physician and later translator of Keill remarked that he used the 'same Instruments and Means' as Sanctorius.94

Keill also included in Medicina statica Britannica a short notebook in which he recorded activity, diet, and the phases of the moon which he felt might affect his excretory processes. From these remarks a picture of Keill emerges during this period as a generally healthy man except for an infrequent cough or head cold. His only self-medication was an occasional purge such as Glauber's salts, although his choice of drink might have been influenced by a supposed therapeutic value such as Bath water or chalybeate water. He also enjoyed mead, punch, Bohea tea, green tea and wine, but as the rest of his life suggests, he was basically a man of caution and moderation, for which reason he once noted that he 'drank more wine than usual, but only to Chearfulness, which I always mean by this Expression'. 95

The final part of Medicina statica Britannica contained a series of sixty-six aphorisms which Keill deduced from his tables and notebook of daily observations. They include a few health precepts and many generalizations in which Keill attempted to relate numerically intake and excretion. Unfortunately Keill's aphorisms, which represent the core of the work, cannot be described as profound contributions to the study of metabolism, and it is perhaps best to consider the entire work as a praiseworthy attempt at scientific verification-specifically of the work of Sanctorius whose example Keill follows closely. However, Medicina statica Britannica attracted sufficient contemporary interest to prompt John Quincy to append his translation of Keill's aphorisms and a commentary on them to the second and subsequent editions of his translation of the aphorisms of Sanctorius, Medicina statica (London, 1720).

A final section of Keill's 1718 Tentamina consisted of two essays. The title of the first declared that 'An obstructed Perspiration is not the cause of catching Cold'. Rather Keill attributed it to 'frigorifick particles' in the air which were absorbed into the blood and promoted the union of particles of blood 'so that the Humour which is formed by these Copulae, flows in more than usual Quantity upon the Glands of the Lungs, Throat, or Nose'. ${ }^{96}$

The theory was obviously designed to harmonize with Keill's notions regarding forces of attraction which also prompted the second essay, 'Of the attracting Force of an animated Body'. In this lengthy discourse Keill explained, amidst a commentary

os Ibid., preface.

o4 S. Sanctorius, Medicina statica, tr. by J. Quincy, London, 1720, preface.

os J. Keill, Essays on Several Parts of the Animal Oeconomy. The fourth edition to which is added, a dissertation concerning the force of the heart, by James Jurin, M.D., F.R.S. with Dr. Keill's answer, and Dr. Jurin's reply. Also medicina statica Britannica, or statical observations, made in England, by James Keill, M.D. Explained and compared with the aphorisms of Sanctorius, by John Quincy, M.D., London, 1738, p. 229.

"Ibid., p. 274. 


\section{James Keill of Northampton}

on the history of ancient science, that a living body attracted moisture into itself from the air, a factor to be considered in selecting the proper environment for a patient.

There was a fourth posthumous edition of Keill's physiological Essays ${ }^{97}$ published in 1738 which reverted to the text of the second edition except for the preface which was translated from the Latin. It also included translations of Keill's and Jurin's essays on the force of the heart and a complete translation of Medicina statica Britannica. Therefore, strictly speaking, this edition presents the widest selection of Keill's work in English while only the third edition represents the final expression of its author's views.

Concerning the remainder of Keill's life, some information is provided by the last two letters in the Keill-Sloane correspondence which deal with two more patients. The first case emphasizes what is fairly well apparent in previous ones, that is, that Keill was acting in the role of Sloane's assistant. In this letter of 27 July 1718 concerned with a Mr. Isted who was suffering from urticaria, Keill wrote as so often, 'I promised Mrs. Isted to write to you last post'.98

Still another patient turned over to Keill was a Miss Samwell who had gone to Northamptonshire for a change of air. In a letter of 7 February 1718-19 Keill regretted that it had produced no improvement, although he hoped her malady-perhaps, in modern terms, tuberculosis-might respond in time.99

It is against this combination of his final scientific works and his medical practice that one should view Keill's own last illness. Until 1716 Keill's only serious medical problem had been his bout with bladder stones. In that year, however, he became afflicted with more serious ailments which eventually resulted in his death. John Rushworth (1669-1736) the aforementioned surgeon, ${ }^{100}$ treated Keill in his last months and wrote an account of the case in order to defend himself against professional criticism. ${ }^{101}$ However, despite Rushworth's obvious attempt to produce a thorough report, the exact nature of Keill's illness is still difficult to interpret in modern terms.

In August 1716 Keill complained of a tumour in his mouth, whereupon Rushworth incised the tumour and noted that 'there appear'd to be nothing contain'd in it, but Blood'. Keill consulted 'several Physicians and Surgeons' in London who agreed with Rushworth that the only way to remove the tumour was by cauterization. Keill recovered from this procedure and remained well for twenty months.

However, in April 1718 Keill noted a spreading ulceration at the site-of the tumour with involvement of the adjacent bone and tooth. Rushworth again suggested cauterization, but despite four such attempts at treatment the ulcer continued to spread. Keill resolved upon further medical consultation and upon the advice of two surgeons, Palmer and Brown, allowed a tooth to be pulled and underwent a series of mercurial purges. Neither this treatment stopped the spread of the ulcer nor apparently did 'all the good internal Methods continually used by the concurring Advice of Dr. Mead, Dr. Freind, and several other Eminent Physicians'.

One of the 'other Eminent Physicians' had evidently been Sloane upon whose

"7 For full title, see note 95 .

os British Museum, Sloane Mss. 4045, fol. 134.

99 British Museum, Sloane Mss. 4045, fol. 190.

100 Cf. the biography in the Dictionary of National Biography.

101 J. Rushworth, The Case of the late James Keil, Dr. of Physick, Oxford, 1719. 


\section{F. M. Valadez and C. D. O'Malley}

recommendation Keill had taken antimony and 'bezoar minerals' for more than four months. However the results had been discouraging and Keill wrote to Sloane 'finding myself rather to grow worse I am at last resolved to try a salivation and intend to begin this week'. ${ }^{102}$

To carry out Keill's desire Rushworth advised small doses of calomel although he was opposed by Palmer, Brown and also John Freind who was kept appraised of events by an anxious John Keill. They preferred mercurial unction which indeed Rushworth adopted as his next course of treatment followed by mercurial fumigation. Unfortunately, soon after the cessation of this therapy, a hard swelling of the lower face and neck supervened and eventually caused Keill's death by suffocation on 16 July 1719. He was buried in the yard of St. Giles' Church, Northampton, where a memorial inscription was erected to him by his brother. ${ }^{103}$

It is difficult to decide whether the ultimate cause of Keill's death was a cancerous process as Rushworth believed or rather a series of infections culminating in a massive septic lymphadenopathy. The end result was the same and perhaps one should value Rushworth's account more as a touching description of the helplessness of the eighteenth-century physician and the forbearance of an eighteenth-century patient, in particular Keill, who despite the variety of unpleasant treatments he was called upon to endure was 'Chearful, and to all outward Appearance tolerably Easy to the Last'. ${ }^{104}$

Keill's last months may have been somewhat lightened by a reconciliation with his brother and his new wife who seems to have produced the only minor discord in the otherwise harmonious relationship between the two brothers. In 1717 John was married to Mol Clements, a servant and daughter of a bookbinder in what for John was a satisfying match. A contemporary remarked how John 'talks like a philosopher; he has been married five months, and says he likes his wife better now than he did before he married her. That she is that which is agreeable to him, that she is one who will live just as he would have her . . ${ }^{105}$ Nonetheless James apparently questioned his brother's relationship for on 17 November 1718 Thomas Hearne wrote that John was married at the 'Importunity of his Brother, Dr. James Keill, M.D. . . . being not satisfied yt he was married before. Nor indeed, were others satisfied, he not being able to produce any certificate.' 106

Complete family harmony, however, apparently did not develop until the fatal outcome of James' illness had become apparent. John, who had already taken an interest in his brother's health, brought his wife to visit James as he lay ill at Northampton whereupon 'she behaved to him on this occasion with so much prudence and assiduity to please, as in a few months softened him into a perfect reconciliation; and at his death (which happened in a little time) he left the married couple in possession of a considerable fortune.' 107

James Keill's will did indeed leave the bulk of his estate to his brother although

102 British Museum, Sloane Mss. 4045, fol. 190.

103 For inscription and translation, see R. M. Serjeantson, A History of the Church of St. Giles, Northampton, 1911, pp. 149-50.

${ }_{104}$ Rushworth, op. cit., p. 4.

${ }^{105}$ Historical Manuscripts Commission, Report on the Manuscripts of his Grace the Duke of Portland, K.G. preserved at Welbeck Abbey, London, 1901, vol. 7, p. 229.

106 Hearne, op. cit., vol. 6, p. 251.

107 Biographia Britannica, vol. 4, p. 2806. 


\section{James Keill of Northampton}

he made a number of lesser bequests in which he remembered, as aforementioned, his 'Brother and Sister Gordon' ( $£ 10$ apiece), his 'Brother Murray' ( $£ 10)$, his sister Magdalen Murray and her children ( $£ 800)$, his uncle Dr. Cockburn (£150), and his goddaughters Ann Downes, daughter of the bishop of Killala, Ireland, and Mary Rushworth, daughter of John Rushworth ( $£ 5$ apiece). He also left $£ 10$ to the poor of Northampton and $£ 100$ for "putting out eight to ten poor Boys of the Charity School of Northampton, apprentices to learn some good and usefull handycraft Trade.'

Keill bequeathed his microscopes and all his books to Matthew Lee, reserving only to John Keill the right to keep the books of six authors of his choice. Lee (16941755), ${ }^{108}$ at that time a twenty-five-year-old student at Christ's Church College, Oxford, had been born in Northamptonshire and may have been some sort of protégé of Keill although nothing further of their relationship is known. At any rate Keill's generosity to him did not prove to be unjustified in view of Lee's later career as a prominent London physician and as a benefactor to anatomical studies who donated money to endow an anatomical lectureship at Christ's Church in 1750 and to build an anatomy school. One might well say that Keill's final, if indirect, legacy to anatomy was his assistance to this young scholar.

It is perhaps Keill's anatomical texts and their role in providing sound basic knowledge to generations of students which constitute his most enduring achievement. As a practising physician of his era who was generally bound by the traditions of his age, Keill was neither exceptionally good nor bad. If one considers Keill as a physiologist, one is hard pressed to find a lasting major contribution made by him although his work suggested a few new problems and did at least constitute a rational attempt at creating a quantitative physiology. It was unfortunate for Keill's later reputation that after the researches of Stephen Hales, the quantitative approach to physiological research in England became overshadowed by a growing concern with vitalism. The editors of the abridgement to the Philosophical Transactions refused to translate the Keill-Jurin essays on the force of heart, with the comment 'Such calculations display great ingenuity, but they are necessarily involved in much uncertainty, being founded on data taken from inanimate matter, the laws of which are not applicable to organs endowed with the principle of vitality.' ${ }^{109}$ Writing in a similar vein, John Bell, in an introductory account of medical history disparaged those doctrines which had rendered famous the names of Bellini, Pitcairne, Keill, Hales, and other 'mechanical physicians, whose books are gone with them to the vault of all the Capulets'.110

Thus each age may make its own judgment of Keill and his works as indeed each modern reader may wish to place an evaluation upon the different aspects of Keill's life other than what this article has suggested. Whatever lasting merit one awards to Keill's accomplishments certainly his life represents the career of an eighteenthcentury physician in its fullest and most varied state.

ACKNOWLEDGEMENT

The authors wish to acknowledge with deep appreciation the assistance of the following people: Miss J. Dobson, Dr. R. Walter, and Dr. A. Verity.

$108 \mathrm{Cf}$. the biography in the Dictionary of National Biography.

${ }_{109}$ Philosophical Transactions of the Royal Society of London, abridged, ed. C. Hutton, G. Shaw, and $R$. Pearson, London, 1809, vol. 6, p. 375.

${ }_{110} \mathrm{~J}$. Bell, The Anatomy of the Human Body, Edinburgh, 1797, vol. 2, p. vi. 